\title{
Scaling up the Phytochemical Contents in the Leaves of Beetroot Using a Formulated Antioxidant Gawda ${ }^{\circledR}$
}

Elwakil, M. A. ${ }^{1}$; M. A. El-Metwally ${ }^{2}$; A. E. Khalil ${ }^{2}$ and K. N. Eisa ${ }^{2}$

${ }^{1}$ Plant Pathology Department, Faculty of Agriculture, Mansoura University, El-Mansoura, 35516, Egypt

${ }^{2}$ Plant Pathology Research Institute, Agricultural Research Center, Giza, Egypt

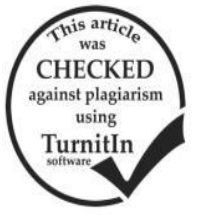

\section{ABSTRACT}

Beetroot (Beta vulgaris L.) have been used for many years as a food supplement to support treating a number of diseases. It is also classified as medicinal plant because of its excellent source of phytochemicals including antioxidants, minerals, vitamins and amino acids. Beetroot are vegetable belong to the family Chenopodiaceae. In food industry they are formulated in edible powder and energetic juice. In some regions of the world beetroot leaves are cut off and discard in spite of their health benefit because of lack of knowledge among the local people regarding their health benefit. So far, this investigation aimed to evaluate the possible role of the formulated antioxidant GAWDA ${ }^{\circledR}$ on enhancing the phytochemicals of the content of beetroot leaves. P.P, Proline, Potassium and the antioxidant activity were determined. Beetroot seeds were soaked in water solution of GAWDA ${ }^{\circledR}$ formulation $(2 \mathrm{~g} / \mathrm{L}$ for 12 hours $)$ pre sowing $v s$ tap water in case of the check. The target physiological characters were recorded in leaves of 3 month old plants. The results showed that soaking seeds in water solution of GAWDA ${ }^{\circledR}$ formulation $(2 \mathrm{~g} / \mathrm{L}$ for $12 \mathrm{~h})$ before sowing significantly increased the contents of Ch. A, B, carotenoids, total phenolic compounds, proline, potassium and antioxidant activity in the plant leaves. The potential of the formulated antioxidant $\left(\mathrm{GAWDA}^{\circledR}\right)$ for scaling up the contents of the phytochemicals studied beetroot leaves was concluded.

Keywords: Beetroot (table beet), formulated antioxidant GAWDA ${ }^{\circledR}$, p.p phenols, proline, potassium, carotene.

\section{INTRODUCTION}

Since several decades the use of food supplements has increased day after another mainly in forms of crude extracts ${ }^{1}$. Many leafy vegetables contain ascorbic acid, beta-carotene, minerals, phenols, fibers and others Negi and Roy (2001), which increases the immunity against several diseases including cardiovascular diseases, cataracts, and brain and immune dysfunction Vinson and Hontz (1995). Beetroot (Beta vulgaris) which is a member of the family Chenopodiaceae, consists a good number of important compounds which support the body against many diseases. This plant is commonly used in the Mediterranean basin since 1000 B.C. Vali et al. (2007). A number of studies are handling their biological activities including the potent antioxidants and free radical scavengers Marja et al. (1999). In addition, to their chelation potential Ramarathnam et al. (1997); Kuo et al. (1998). Both, roots and leaves of beetroot consist high level of phenolic compounds Marja et al. (1999). They are used in some areas of the world as a remedy for kidney and liver diseases Kanner and Granit (2001). As beetroot leaves are highly and cheap source of nutrients. The present study aimed to evaluate the role of formulated antioxidant GAWDA $^{\circledR}$ on enhancing the constituent of the phytochemical compounds in the leaves of beetroot plant.

\section{MATERIALS AND METHODS}

This investigation was carried out at the laboratories and experimental field plots of Plant Pathology Department, Mansoura University during growing season of 2016-2017. Beetroot seeds cv. Detroit superene Hybrid used in this study was obtained from Bakker Brothers Co., Holland.

\section{Experimental design}

One Way Completely Randomized design with 6 replicates was followed.

\section{Formulated Antioxidant used}

GAWDA $^{\circledR}$ formulation, Patent No. 23798 (consists of calcium borate $5 \mathrm{mM}+$ calcium chloride $6 \mathrm{mM}+$ magnesium chloride $5 \mathrm{mM}+\operatorname{tartaric}$ acid $2 \mathrm{mM}+$ hydroxyquinoline $1 \mathrm{mM}$ ) was used in this investigation. Before sowing, beetroot seeds were soaked in water solution of GAWDA ${ }^{\circledR}$ formulation at a rate of $(2 \mathrm{~g} / \mathrm{L})$. Tap water was used as a control. Soaking period was $12 \mathrm{~h}$. Leaves from three month old plants were harvested to assess the concentrations of the target constituents.

\section{Chemical assay:}

\section{1- Photosynthetic pigments}

The third upper leaf of the beetroot plants was used for chl. a, b as well as carotenoids were investigated, while ten $\mathrm{mL}$ methanol $(90 \%)$ was determination according to Mackinney (1941): methanol was used for extraction.

\section{2- Total phenols}

The content of the total phenols in the lower leaves of the plants was determined using Foline-ciocalteau reagent Singleton and Rossi (1965)

Results were calculated as mg catechol/100 g fresh weight (fw).

\section{3- Proline content}

Proline content was also determined in the lower leaves following the method of Bates et al. (1973).

\section{4- Antioxidant activity}

The assessments of the antioxidants were measured in the forms of radical scavenging ability to use stable free radicals (diphenylpicrylhydrazyl) (DPPH) radical Fradovich (1986); Daivies (2000) according to the method of (Teraos et al. (1988).

\section{5- Total potassium}

The concentration of total potassium content (mg/100g dry weight) were determined in leaves using the method of Chapman and Pratt $(1961 ; 1982)$.

\section{Statistical analysis}

Data was statistically analyzed using COSTAT (2005) software Gomez and Gomez (1984). The means were compared using the least Significant Difference (LSD) of the means and compared at $p=0.05$ as outlined by Duncan(1955). While the means followed by different letter(s) in the all columns of the tables show significantly different according to Duncan's multiple range test at $p=0.05$. 


\section{RESULTS AND DISCUSSION}

Results

Effect of the formulated antioxidant $\left(\right.$ GAWDA $\left.^{\circledR}\right)$ on the photosynthetic pigments:

Table(1) shows that soaking the seeds in the water solution of GAWDA ${ }^{\circledR}$ formulation at $2 \mathrm{~g} / \mathrm{L}$ before sowing significantly increased the content of total chlorophylls as they recorded $(2.741 \mathrm{mg} / \mathrm{g} \mathrm{F} . W)$, ch A $(1.828 \mathrm{mg} / \mathrm{g} \mathrm{fw})$, ch B $(0.913 \mathrm{mg} / \mathrm{g} \mathrm{F.W})$ and carotenoid $(0.306 \mathrm{mg} / \mathrm{g} \mathrm{F} . W)$. In the check, total chlorophyll recorded $(2.415 \mathrm{mg} / \mathrm{g} \mathrm{F.W})$, ch A $(1.700 \mathrm{mg} / \mathrm{g} \mathrm{F.W})$, ch B $(0.715 \mathrm{mg} / \mathrm{g} \mathrm{F.W})$, while carotenoid recorded $0.133 \mathrm{mg} / \mathrm{g}$ F.W.

Table 1. Impact of the antioxidant GAWDA ${ }^{\circledR}$ formulation on the concentration of photosynthetic pigments in the $3^{\text {rd }}$ upper leaf of beetroot plants.

\begin{tabular}{lcccc}
\hline Treatment & $\begin{array}{c}\text { Ch A } \\
\mathbf{m g} / \mathbf{g} \\
\text { Fresh } \\
\text { weight }\end{array}$ & $\begin{array}{c}\text { Ch B } \\
\mathbf{m g} / \mathbf{g} \\
\text { Fresh } \\
\text { weight }\end{array}$ & $\begin{array}{c}\text { Total } \\
\text { chlorophyll } \\
\text { mg/g Fresh } \\
\text { weight }\end{array}$ & $\begin{array}{c}\text { Carotenoid } \\
\mathbf{m g} / \mathbf{g} \\
\text { Fresh } \\
\text { weight }\end{array}$ \\
\hline $\begin{array}{l}\text { GAWDA }^{\circledR} \\
\text { formulation }\end{array}$ & $1.828 \mathrm{a}^{*}$ & $0.913 \mathrm{a}$ & $2.741 \mathrm{a}$ & $0.306 \mathrm{a}$ \\
\hline Check & $1.700 \mathrm{~b}$ & $0.715 \mathrm{~b}$ & $2.415 \mathrm{~b}$ & $0.133 \mathrm{~b}$ \\
\hline
\end{tabular}

Effect of GAWDA ${ }^{\circledR}$ formulation on total phenols in the leaves:

Results revealed in Table (2) show that soaked seeds in the water solution of GAWDA ${ }^{\circledR}$ formulation at 2 $\mathrm{g} / \mathrm{L}$ significantly increased the content of total phenols in the plant leaves. It recorded $244.97 \mathrm{mg}$ catechol/100g fw. Whereas $183.96 \mathrm{mg}$ catechol/100g fw in the check.

Table 2. Impact of GAWDA ${ }^{\circledR}$ formulation on the total phenols content in the leaves of beetroot plant.

\begin{tabular}{lc}
\hline Treatment & $\begin{array}{c}\text { Total phenol mg catechol/ } \\
\mathbf{1 0 0} \text { g fresh weight }\end{array}$ \\
\hline GAWDA $^{\circledR}$ formulation & $244.97 \mathrm{a}^{*}$ \\
Check & $183.96 \mathrm{~b}$ \\
\hline
\end{tabular}

Impact of GAWDA ${ }^{\circledR}$ formulation on proline:

Results revealed that soaking seeds in the water solution of GAWDA ${ }^{\circledR}$ formulation increased the content of total proline in the plant leaves (Table3). It recorded .193

$0 \mu \mathrm{M} / \mathrm{g}$ fw and $0.167 \mu \mathrm{M} / \mathrm{g}$ fw in the treated and untreated plant, respectively.

Table 3. Impact of GAWDA ${ }^{\circledR}$ formulation on proline content in leaves of beetroot plants

\begin{tabular}{lc}
\hline Treatment & Proline $\left(\boldsymbol{\mu M} / \mathbf{g}^{-1}\right.$ tissue $)$ \\
\hline GAWDA $^{\circledR}$ formulation & $0.193 \mathrm{a}^{*}$ \\
Check & $0.167 \mathrm{~b}$ \\
\hline
\end{tabular}

Impact of GAWDA ${ }^{\circledR}$ formulation on antioxidants activity (DPPH):

Table 4 shows that DPPH \% activity was significantly increased to record $65.62 \%$. While in the check it recorded $25.24 \%$.

Table 4. Effect of GAWDA ${ }^{\circledR}$ formulation on antioxidant activity (DPPH) in the leaves of beetroot plants.

\section{Treatment}

\begin{tabular}{lc} 
Treatment & Scavenging activity $(\%)$ \\
\hline GAWDA $^{(\circledR)}$ formulation & $65.62 \mathrm{a}^{*}$ \\
Check & $25.24 \mathrm{~b}$ \\
\hline
\end{tabular}

Impact of GAWDA ${ }^{\circledR}$ on Potassium content:

The content of potassium also presented a highly significant increases to reached $1672.54 \mathrm{mg} / 100 \mathrm{~g}$ while, the check recorded $312.41 \mathrm{mg} / 100 \mathrm{~g}$ (Table 5).

Table 5. Impact of antioxidant (GAWDA ${ }^{\circledR}$ formulation) on Potassium content level in the leaves of beetroot plants.

\begin{tabular}{lc}
\hline Treatment & Potassium content \\
& $\mathbf{m g} / \mathbf{1 0 0 g}(\mathbf{d r y}$ weight $)$ \\
\hline GAWDA $^{\circledR}$ formulation & $1672.54 \mathrm{a}^{*}$ \\
Check & $312.41 \mathrm{~b}$ \\
\hline
\end{tabular}

\section{Discussion}

Results revealed that soaking seeds in GAWDA ${ }^{\circledR}$ formulation at $2 \mathrm{~g} / \mathrm{L}$ before sowing increased in the content of photosynthic pigments, total phenols, proline, antioxidant activity (DPPH) and potassium in the beetroot leaves. Amtmann et al (2006) indicated that potassium is a vital element in the life of human and has a role in the metabolism, enzyme activity and polarization of cell membrain. It has also a profitability role in the physiological processes in plants i.e.: photosynthesis, photorespiration and its growth. Rai et al. (2002); Marschner (2012) This riches might attributed to the antioxidant efficiency as assimilator for enhancing $\mathrm{N}$ uptake, regulation of cellular $\mathrm{pH}$, activating phytohormone and enzymatic systems. This research indicated that using antioxidants as a seed treatment for sure enhance the contents of phenolic compounds and increase the level of potassium in the vegetative parts of the plants. Moreover, it's a promising tactic for scaling up the useful nutrients in beetroot plants.

\section{REFERENCES}

Abdel-Hameed, E. S.; S. A. Bazaid; M. M. Shohayeb; M. M. El-Sayed and E. A. El- Wakil (2012): Phytochemical Studies and Evaluation of Antioxidant, Anticancer and Antimicrobial Properties of Conocarpus erectus L. Growing in Taif, Saudi Arabia. European Journal of Medicinal Plants. 2(2): 93- 112.

Amtmann, A.; J.P. Hammond; P. Armengaud and P.J. White (2006): Nutrient sensing and signalling in plants: Potassium and phosphorus. Adv. Bot. Res. 43:209-257.

Bates, L.S.; R.P. Waldren and I.D. Teare (1973): Rapid determination of free proline for water-stress studies. Plant Soil, 39: 205-207.

Chapman, H.D. and P.F. Pratt (1961): Methods of Analysis for Soils, Plants and Waters. Agriculture Science, University of California, Berkeley, Pages: 309.

Chapman, H.D. and P.F. Pratt (1982): Methods of Plant Analysis, I. Methods of Analysis for Soil, Plant and Water Chapman Publishers, Riverside, California, USA.

COSTAT (2005): CoHort Software. Version 6.311, Lighthouse Ave, Monterey, CA., USA

Daivies, K. J. A. (2000): Oxidative stress, antioxidant defenses, and damage removal, repair, and replacement systems. IUBMB Life.50: 279 - 289.

Duncan, D.B. (1955): Multiple range and multiple $F$ tests. Biometrics, 11: 1-42. 
Fradovich, I. (1986): Biological effects of the superoxide radical. Arch Biochem Biophys. May 15; 247(1):111.

Gomez, K.A. and A.A. Gomez (1984): Statistical Procedures for Agricultural Research. 2nd Edn., John Wiley and Sons Inc., New York, USA., pp: 95-109.

Kanner, J.; S. Harel and R. Granit (2001): Betalains: a new class of dietary cationized antioxidants. J. Agric. Food. Chem., 49: 5178-5185.

Kuo, S. M.; P. S. Leavitt; and C. P. Lin (1998): Dietary flavonoid interact with trace metals and affect metallothionein level in human intestinal cells. Biological Trace Element Research, 62: 135-153.

Mackinney, G. (1941): Absorption of light by chlorophyll solutions. J. Biol. Chem., 104: 315-322.

Marja, P. K.; I. H. Anu; J. V. Heikki; R. Jussi-Pekka; P. Kalevi; S. K. Tytti and H. Marina (1999): Antioxidant activity of plant extracts containing phenolic compounds. J. Agric. Food Chem., 47: 3954-3962.

Marschner, P. (2012): Marschner's Mineral Nutrition of Higher Plants, 3rd ed.; Academic Press: London, UK, pp. 178-189.

Negi, P.S. And S.K. Roy (2001): Effect of drying conditions on quality of green leaves during long term storage. Food Research International., 34: 283-287.
Rai, G.K.; M.M. Verma and J. Singh (2002): Nitrogen and potassium interaction effect on yield attributes of potato. J. Indian Potato Association, 9(3-4): 153154.

Ramarathnam, N.; H. Ochi and M. Takeuchi (1997): Antioxidant defense system in vegetable extracts. In F. Shahidi (Ed.), Natural antioxidants; chemistry, health effects and applications. Champaign, IIL: AOCS Press. (pp. 76-87).

Singleton, V.L. and J.A. Jr. Rossi (1965): Colorimetry of total phenolics with phosphomolybdicphosphotungstic acid reagents. Am. J. Enol. Viticult., 16: 144-158.

Teraos, K.K.; N. Shinamoto and M. Hirata (1988): Studies on Scavengers of Active Oxygen Species. 1. Synthesis and Biological Activity of 2-O Alkylascorbic Acids. Journal of Medicinal Chemistry, Vol. 31, No. 4, pp. 793-798.

Vali, L.; E. Stefanovits-Banyai; K. Szentmihalyi; H. Febel; E. Sardi and A. Lugasi ( 2007): Liver-protecting effects of table beet (Beta vulgaris var. Rubra) during ischemia- reperfusion. Nutrition., 23:172-8.

Vinson, J. A. and B. A. Hontz (1995): Phenol antioxidant index: comparative antioxidant effectiveness of red and white wines. J. Agric. Food Chem., 43: 401403.

\section{زيادة محتويات المواد الكيميائية التباتية في أوراق الثمندر باستخدام مركب مـ GAWDA المضاد للأكسدة

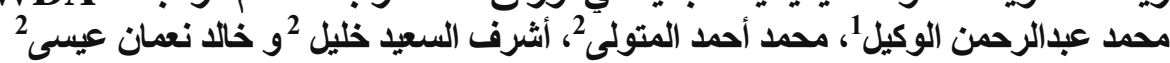

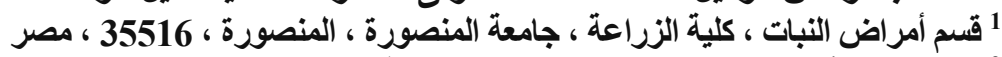

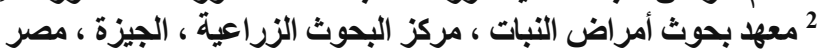

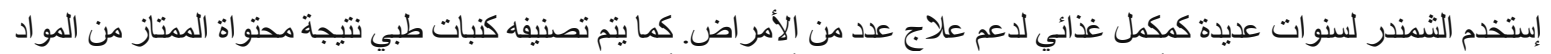

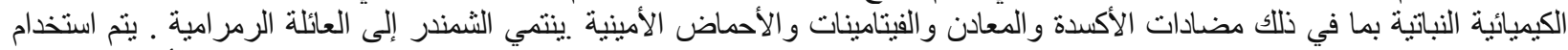

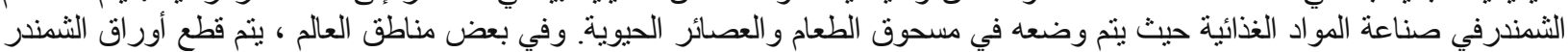

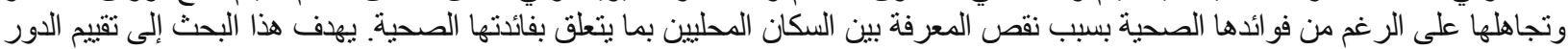

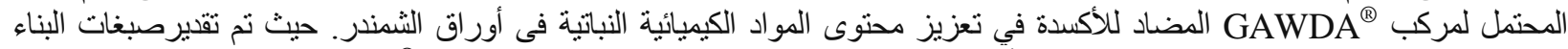

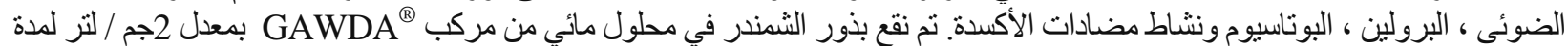

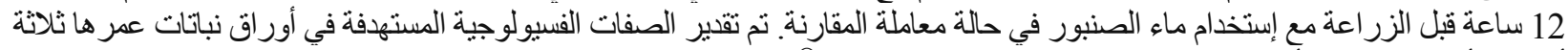

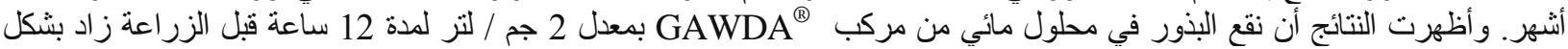

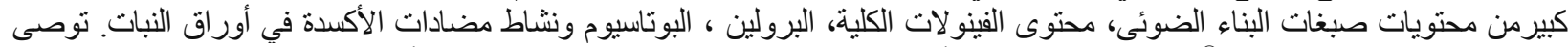
الدر اسة بإمكانية إستخدام مركب ${ }^{\text {G }}$ 